\title{
Erratum zu: Elektrizitätswirtschaft, Liberalisierung
}

\section{Erratum zu:}

Kapital 3 in Valentin Crastan, Elektrische Energieversorgung 2, https://doi.org/ 10.1007/978-3-662-48965-9_3

Das Kapitel 3 wurde versehentlich vor Druckfreigabe vom Autor veröffentlicht. Das Kapitel wurde jetzt überarbeitet. In der korrigierten Version finden Sie die finale inhaltliche und vom Autor freigegebene Fassung. https://doi.org/10.1007/978-3-662-48965-9_3

Die aktualisierte Version des Kapitels kann hier abgerufen werden: https://doi.org/10.1007/978-3-66248965-9_3 